\title{
GAMBARAN SUBJECTIVE WELL-BEING PADA PEREMPUAN LANJUT USIA
}

\section{DESCRIPTION OF SUBJECTIVE WELL-BEING IN ELDERLY WOMEN}

\author{
Lia Kaulina Suci Ningtyas ${ }^{1}$, Fatwa Tentama ${ }^{2}$, Nina Zulida Situmorang ${ }^{3}$ \\ Program Studi Magister Psikologi Sains,Fakultas Psikologi \\ Universitas Ahmad Dahlan \\ Jalan Kapas No.9, Semaki, Umbulharjo, Semaki, Umbulharjo, Kota Yogyakarta, Daerah Istimewa Yogyakarta \\ 55166 \\ ${ }^{1}$ lia.kaulina@gmail.com, ${ }^{2}$ fatwa.tentama@psy.uad.ac.id, ${ }^{3}$ nina.situmorang@psy.uad.ac.id
}

\begin{abstract}
ABSTRAK
Perempuan lanjut usia (lansia) sangat rentan terhadap diskriminasi ganda, baik karena statusnya sebagai lansia maupun perempuan. Perubahan dalam kehidupan lansia umumnya berpotensi pada munculnya tekanan hidup karena stigma menjadi tua dianggap sebagai usia yang dikaitkan dengan kelemahan, ketidakberdayaan, dan rentan terhadap penyakit. Salah satu faktor yang berperan penting dalam menentukan kualitas hidup adalah Subjective well-being (kesejahteraan subjektif). Subjective well-being merupakan evaluasi seseorang tentang kehidupannya. Evaluasi yang dilakukan berupa evaluasi kognitif yang meliputi kepuasan hidup serta evaluasi emosi yang berupa jumlah frekuensi yang dialami seseorang tentang afek positif dan afek negatif. Kajian ini bertujuan memaparkan informasi mengenai gambaran subjective well-being pada perempuan lansia dan faktor-faktor yang mempengaruhinya dengan menggunakan metode kajian pustaka yang diharapkan dapat menjadi landasan untuk penelitian selanjutnya dengan tema yang sama. Kajian ini juga dapat dijadikan sebagai informasi pendukung bagi para pemegang kebijakan dalam membuat perencanaan program aktif yang mendukung perempuan lansia dan intervensi yang dapat memberdayakan perempuan lansia sebagai anggota masyarakat. Temuan dari kajian ini menunjukkan bahwa faktor-faktor yang mempengaruhi subjective well-being pada perempuan lansia adalahhubungan sosial, dukungan keluarga, religiusitas dan efikasi diri.
\end{abstract}

Kata kunci: kebahagiaan, perempuan lanjut usia,subjective well-being 


\title{
The $8^{\text {th }}$ University Research Colloqium 2018 Universitas Muhammadiyah Purwokerto
}

\begin{abstract}
Elderly women are very vulnerable to double discrimination, both because of their status as elderly and women. Changes in the lives of elderly people generally have the potential for the emergence of life pressure because stigma of aging is considered to be an age that is associated with weakness, powerlessness, and susceptibility to disease. One factor that plays an important role in determining the quality of life is Subjective well-being. Subjective well-being is a person's evaluation of his life. The evaluation was in the form of cognitive evaluation which included life satisfaction and emotional evaluation in the form of the number of frequencies a person experienced about positive affect and negative affect. This study aims to explain information about subjective well-being images of elderly women and the factors that influence them by using literature review methods which are expected to be the basis for further research with the same theme. This study can also be used as supporting information for policy holders in making active program planning that supports elderly women and interventions that can empower elderly women as community members. The findings of this study indicate that the factors that influence subjective well-being in elderly women are social relations, family support, religiosity and self eficacy.
\end{abstract}

Keywords: hapiness, elderly women,subjective well being 


\section{PENDAHULUAN}

Lanjut usia (lansia) adalah tahap terakhir dari masa dewasa, sehingga masa lansia sering juga disebut sebagai masa dewasa akhir sebelum memasuki tahap terakhir dari perkembangan manusia yaitu kematian. Masa lansia, yang biasanya dimulai pada usia 65 tahun, ditandai dengan banyaknya perubahan dalam hidup individu lansia secara fisik, kognitif, dan psikososial (Papalia, Olds, \& Feldman, 2009). Orang lanjut usia adalah sebutan bagi mereka yang telah memasuki usia 60 tahun ke atas. Undang-Undang Republik Indonesia Nomor 13 Tahun 1998 tentang Kesejahteraan Lanjut Usia Bab 1 Pasal 1, yang dimaksud dengan Lanjut Usia adalah seseorang yang telah mencapai usia 60 (enam puluh) tahun ke atas. Lanjut Usia Potensial adalah lanjut usia yang masih mampu melakukan pekerjaan dan kegiatan yang dapat menghasilkan barang atau jasa. Lanjut Usia Tidak Potensial adalah lanjut usia yang tidak berdaya mencari nafkah sehingga hidupnya bergantung pada bantuan orang lain. (Indriana, 2012).

Secara fisik, individu yang telah berusia 65 tahun ke atas tentunya mengalami perubahan bertahap dari kondisi tubuhnya yang sehat menuju kondisi yang memprihatinkan seperti rasa sakit dan penyakit. Namun, ada beberapa individu lansia masih dapat bertahan dalam kondisi sehat dan tetap menikmati banyak kegiatan yang dilakukannya ketika masih muda dulu. Secara kognitif, individu lansia mengalami kemunduran dalam proses penalarannya, namun dapat mencari strategi untuk menyesuaikan diri terhadap perubahan tersebut. Secara psikososial, individu lansia menyesuaikan diri dalam menghadapi perubahan yang terjadi di lingkungannya, seperti kematian orang yang dikasihinya dan waktunya untuk pensiun dari pekerjaannya (Papalia, Olds, \& Feldman, 2009). Feldman (2012) menyatakan bahwa masa lansia dimulai dari usia 65 tahun ke atas. Santrock (2011) menyebut masa lansia dimulai dari 60 tahun ke atas sampai sekitar 120 tahun atau
125 tahun yang merupakan perkiraan masa hidup terlama manusia zaman sekarang.

Berdasarkan hasil survei yang dilakukan oleh Administration of Aging (Papalia,Old\& Feldman 2009) diperoleh bahwa populasi lansia usia enam puluh tahun ke atas akan melambat di negaranegara maju namun akan tetap meningkat di negara berkembang. Begitu pula data dari Kementrian Kesehatan RI 2017, analisis lansia di Indonesia menunjukkan bahwa terdapat 23,66 juta jiwa penduduk lansia $(9,03 \%)$ diprediksi jumlah penduduk lansia tahun 2025 sekitar 33,69 juta, tahun 2030 sekitar 40,95 juta dan tahun 2035 sekitar 48,19 juta.

Bagi perempuan lanjut usia, masa yang dialami merupakan masa berkurangnya kesibukan pada kehidupannya. Anak-anak telah tumbuh besar dan meneruskan hidupnya masingmasing, pekerjaan sudah ditempati oleh orang lain yang lebih muda, serta pekerjaan rumah sudah tidak sebanyak dulu karena anak-anak sudah tidak dirumah. Menghadapi akibat dari konflik peran ganda yang dialami sebelum perempuan tersebut pensiun juga menjadi penyebab beratnya masa pensiun bagi perempuan di usia senja. Tak heran jika perubahan-perubahan ini memberi dampak seperti tidak percaya diri, tidak puas dengan hidupnya, atau bahkan perasaan sedih dimana menunjukkan Subjective well-being yang rendah.

Istilah kebahagiaan juga banyak dikenal dalam psikologi positif. Teori psikologi menggunakan istilah yang dapat di definisikan secara operasional, yakni Subjective well-being (Seligman, 2005). Dalam praktik, Subjective well-being lebih ilmiah untuk mengartikan istilah kebahagiaan. Subjective well-being dianggap lebih luas dan di definisikan sebagai sisi afektif seseorang (suasana hati dan emosi) dan evaluasi kognitif kehidupan mereka (Seligman \& Csikszenihalyi, 2000). Maka dari itu dalam 
penelitian ini, peneliti menggunakan istilah Subjective well-being.

Menurut Diener (2009) Subjective well-being merupakan evaluasi seseorang tentang kehidupannya. Evaluasi yang dilakukan berupa evaluasi kognitif yang meliputi kepuasan hidup serta evaluasi emosi yang berupa jumlah frekuensi yang dialami seseorang tentang afek positif (perasaan menyenangkan) dan afek negatif (perasaan tidak menyenangkan). Context theories of well-being dikemukakan oleh Winkelman (2006), menyatakan bahwa

\section{METODE PENELITIAN}

Penelitian ini menggunakan metode kajian pustaka. Kajian pustaka merupakan teknik pengumpulan data berupa informasi yang dilakukan peneliti untuk menghimpun data yang relevan dengan

\section{HASIL DAN PEMBAHASAN}

Subjective well-being memiliki makna yang sama dengan kebahagiaan, subjective well-being ini memiliki dua komponen, yaitu komponen kognitif yang berkaitan dengan kepuasan hidup dan komponen afektif yang berkaitan dengan kebahagian individu tersebut. (Diener \& Oishi, 2005). Penelitian tentang konsep kebahagian pada perempuan lansia secara kualitatif telah dilakukan oleh Diponegoro \& Mulyono (2015) dalam jurnal psikopedagogia 4 (1) dengan judul faktorfaktor psikologis yang mempengaruhi kebahagiaan pada lanjut usia suku jawa di Klaten. Hasil penelitian menunjukkan bahwa terdapat 14 faktor yang mempengaruhi kebahagiaan lanjut usia (penghasilan; usia; agama; budaya; bersyukur kepada Tuhan; aktivitas fisik; hubungan sosial; memaafkan; kualitas hidup; silaturahmi; sehat; menikah; berhubungan baik dengan anak, cucu, dan menantu; serta berhubungan baik dengan saudara) dan terdapat 13 afek yang mempengaruhi kebahagiaan lanjut usia (merasa senang, sabar, suasana tenang, optimis, ayem tenteram, trenyuh,
Subjective well-being lahir disebabkan atas timbulnya rasa kepuasan atas kebutuhan universal manusia. Sebaliknya context theories menurut Qiang (2005) menekankan bahwa faktor yang mempengaruhi Subjective well-being sangat bervariasi tergantung waktu dan karakteristik kejadian hidup yang dialami. Berdasarkan latar belakang tersebut, kajian ini bertujuan mengeksplorasi gambaran subjective well-being pada perempuan lansia dan faktor-faktor yang mempengaruhinya.

topik atau masalah yang diteliti. Data tersebut diperoleh melalui buku-buku ilmiah, jurnal atau penelitian terdahulu, dan sumber-sumber tertulis baik tercetak maupun elektronik.

perhatian, bersemangat, tidak dendam, santai, sopan, senang menolong/memberi, dan tidak takut meninggal/pasrah kepada takdir diusia tua).

Hal ini sesuai dengan pendapat Diener (2009) dimana salah satu faktor yang mempengaruhi subjective well-being pada lansia adalah agama dan spiritualitas. Secara umum orang yang religius cenderung untuk memiliki tingkat wellbeing yang lebih tinggi, dan lebih spesifik. Partisipasi dalam pelayanan religius, afiliasi, hubungan dengan Tuhan, dan berdoa dikaitkan dengan tingkat well being yang lebih tinggi. Selain itu, temuan ini juga diperkuat oleh penelitian Muzakkiah \& Suharnan (2016) dalam jurnal psikologi Indonesia bahwasanya ada hubungan antara religiusitas, penyesuaian diri dengan subjective well-being pada jamaah $\mathrm{Al}$ Hidayah Surabaya.

Pali (2016) dalam jurnal e-biomadik menemukan gambaran kebahagiaan pada lansia yang memilih tinggal di panti werdha, bahwa lansia merasa bahagia berada di panti werdha karena 
kebutuhannya terpenuhi namun penelitian lainnya menyatakan bahwa lansia merasa bahagia saat tinggal bersama dengan keluarganya. Dari hasil penelitian tersebut dapat kita ketahui bahwasanya lansia yang tiggal di panti werdha menemukan kebahagiaannya melalui sebuah kebutuhan yang terpenuhi serta kebahagiaan saat tinggal dengan keluarga. Keluarga memiliki pengaruh terhadap faktor kebahagiaan lansia. Hal ini juga sesuai dengan pendapat Taylor (2009) menjelaskan bahwa dukungan sosial keluarga sangat dibutuhkan karena masalah-masalah yang dihadapi lansia berkaitan dengn kesejahteraan psikologinya seperti menurunnya sumber finansial, dan kekuatan fungsi.

$\begin{array}{ccc}\text { Bahkruddiansyah } & \text { (2016) e-journal } \\ \text { psikologi dalam penelitiannya }\end{array}$ menunjukkan bahwa beberapa lansia yang tinggal di panti werdha menemukan makna kebahagiaan dalam menjalani kehidupannya, tidak kesusahan, lebih nyaman dan tidak merasa kesepian. Namun ada yang tidak menemukan kebahagiaan karena merasadirinya tidak berguna. Dari temuan tersebut, dapat diketahui bahwasanya gambaran kebahagiaan lansia di panti werdha dapat ditemukan melalui hubungan sosial yang terjalin. Penelitian yang dilakukan oleh Seligman (2002) juga menunjukan bahwa semua orang yang paling bahagia memiliki kualitas hubungan sosial yang dinilai baik. Hal ini diperkuat oleh teori Diener (2003) yang menyatakan bahwa hubungan yang dinilai baik tersebut harus mencakup dua dari tiga hubungan sosial berikut ini, yaitu keluarga, teman,

\section{KESIMPULAN}

Subjective well-being memiliki makna yang sama dengan kebahagiaan, subjective well-being ini memiliki dua komponen, yaitu komponen kognitif yang berkaitan dengan kepuasan hidup dan komponen afektif yang berkaitan dengan kebahagian individu tersebut. Berdasarkan hasil kajian pustaka dan pembahasan yang telah dilakukan, bahwa gambaran dan hubungan romantis. Temuan lain oleh Fitriyadewi \& Suarya (2016) dalam jurnal psikologi udayana, dimana ada hubungan antara interaksi sosial dengan kepuasan hidup lansia, semakin tinggi interaksi sosial yang dilakukan lansia maka kepuasan hidup lansia semakin tinggi, dan begitu pula sebaliknya apabila interaksi sosial rendah maka kepuasan hidup lansia juga rendah.

Penelitian lainnya oleh Lestari dan hartati (2016) dalam jurnal RAP UNP, dalam penelitiannya menunjukkan terdapat hubungan positif yang signifikan antara self efficacy dengan subjective well being yang tinggal di rumahnya sendiri.Penelitian ini sejalan dengan hasil penelitian yang dilakukan oleh Putri \& Veronika (2014) yang mengungkapkan bahwa untuk dapat meningkatkan subjective well being dilakukan dengan mengatasi perasaan negatif dalam diri yaitu dengan meningkatkan self efficacy. Self efficacy sangat diperlukan untuk mencapai tujuan, memperoleh kepuasan hidup dan emosi positif, self efficacy tinggi akan lebih kuat mencapai subjective well being, sedangkan self efficacy yang rendah akan lemah dalam mencapai subjective well being.

Dari hasil penelitian diatas dapat dilihat bahwasanya faktor yang juga mempengaruhi subjective well being pada lansia adalah dukungan keluarga, hubungan sosial, religiusitas dan efikasi diri. Dengan faktor-faktor tersebut tentu akan mempengaruhi kualitas kehidupan seorang lansia dan juga kebahagiaannya.

subjective well being pada perempuan lansia akan baik apabila faktor-faktor yang mempengaruhinya mengarah pada hal yang positif. Dari beberapa kajian pustaka yang dilakukan, dapat ditemukan beberapa faktor yang mempengaruhi subjective well being pada perempuan lansia adalah hubungan sosial, dukungan keluarga, religiusitas, dan efikasi diri. 


\section{DAFTAR PUSTAKA}

Argyle.M. 2001. The psychology of happines $\left(2^{\text {nd }} e d\right.$.). New York: Routledge.

Bakharudiansyah, Rama. (2016). Makna hidup dan arti kebahagiaan pada lansia di panti werdha nirwana puri samarinda. e-journal psikologi, 4(4), 431-445.

Diener, E., \& Suh, E.M. (2000). Culture and subjective well being. MIT Press.

Diponegoro, M.A, \& Mulyono. (2015). Faktor-faktor psikologis yang mempengaruhi kebahagiaan pada lanjut usia suku jawa di klaten. Jurnal Psikopedagogia, 5(1), 13-19.

Eddington \& Shuman. (2008). Subjective well-being (happiness). California: Continuing psychology education inc.

Fitriyadewi, W.L., \& Suarya, S.K. (2016). Peran interaksi sosial terhadap kepuasan hidup lansia. Jurnal Psikologi Udayana 3(2), 332-341.

Indriana. (2012). Gerontologi \& progeria (ed 1). Yogyakarta: Pustaka Pelajar.

Lestari, A., Hartati, N. (2016). Hubungan self efficacy dengan subjective well-being pada lansia yang tinggal dirumah sendiri. Jurnal RAP UNP. 7(1), 12-23.

Muzakki, N., \& Suharnan. (2016). Religiusitas, penyesuian diri dan subjective well-being. Jurnal Psikologi Indonesia, 5(1), 28-38.

Pali, Cicilia. (2016). Gambaran kebagahagiaan pada lansia yang memilih tinggal di panti werdha. Jurnal e-biomadik, 4(1), 1-7.

Papalia, Olds, \& Feldman, (2009). Human development, (A.K Anwar, Penerjemah.). Jakarta: Kencana.

Qiang, Li (2005). Subjective well-being and mortality in chinese oldest old. Working paper. Rostock, germany: max planck institute for demographic research.

Santrock. (2001). Life-span development, perkembangan masa hidup. Jakarta: Erlangga.

Seligman, Martini E.P. Chirtoper, Peterson (2005). Authentic happiness using the new positive psychology to realize your potential for lasting fullfilment: Menciptakan kebahagiaan dengan psikologi positif (terjemahan). Bandung : PT Mizab Pustaka.

Winkelmann, R (2006). Unemployment, social capital, and subjective well being. University of zurich, socioeconomic institute working paper 0503 . 